\title{
U-Prevent: a rizikóstratifikáció új szemlélete
}

\author{
Vértes András
}

DPC Kórház, Országos Hematológiai és Infektológiai Intézet, Budapest

Levelezési cím: vertesandras@dpckorhaz.hu

Az U-Prevent egy új szemléletet ad a kardiovaszkuláris rizikó meghatározásában. Alkalmas a diabéteszes betegek, és a már kardiovaszkuláris eseményen átesett betegek rizikó meghatározására. Személyre szabott rizikóstartifikáció. Az U-Prevent egy online platform, amely a betegek edukációjában is segítséget nyújt. Az U-Prevent a 10 éves kardiovaszkuláris rizikót vizsgálja, és figyelembe veszi a vérnyomást, koleszterinszintet, vércukorértékek mellett a beállitott kezelést is.

Kulcsszavak: kardiovaszkuláris prevenció, rizikó pontszám, U-Prevent

\section{U-Prevent: New cardiovascular risk strategy}

U-Prevent provides an new approach to defining cardiovascular risk. It is suitable for the risk assessment of diabetic patients and patients who have already undergone cardiovascular events. Personalized risk start-up.U-Prevent is an online platform that aims to provide tools for personalizing cardiovascular disease prevention. These tools may be used for educational or research purposes or to support doctor-patient communication. Individual risk estimations for (recurrent) major cardiovascular events can be used for patient education. These tools may allow patients to gain more insight into their personal prognosis, thereby increasing their health-motivation and positively impacting adherence to prescribed therapy. U-Prevent provides tools to estimate both 10-year and lifetime effects of the most frequently applied preventive interventions, including blood pressure lowering, lipid lowering and platelet aggregation inhibition.

Keywords: cardiovascular prevention, risk-score, U-Prevent

A kardiovaszkuláris betegségek hátterében húzódó ateroszklerózis már gyermekkorban megkezdődhet, és aztán lappangva, tünetmentesen fejlődik ki évek, évtizedek alatt. Ugyanakkor a betegség legtöbb esetben már előrehaladott stádiumban van, amikor felfedezésre kerül, és az esetek 50\%-ában a miokardiális infarktus minden előzetes tünet nélkül jelentkezik. A betegséget el lehetne kerülni megfelelő életmódváltással, a rizikófaktorok eliminálásával, szükség esetén gyógyszeres kezeléssel. Ez az elméleti alapja a preventív megközelítésnek, amelyet aláhúz az a tény, hogy az ateroszklerózis legfőbb okai ismertek és egyértelmű bizonyítékaink vannak arra vonatkozóan, hogy a rizikófaktorok csökkentése/kezelése egyértelmúen javítja az ateroszklerotikus eredetü kardiovaszkuláris betegségek (ASCVD) mortalitását és morbiditását. A látszólag egészséges (tünetmentes) egyénekben a CVD-betegségek kocká- zata legtöbbször a halmozottan fennálló rizikótényezők együttes hatásának köszönhető.

Az utolsó két évtizedben paradigmaváltás történt az ateroszklerotikus eredetű kardiovaszkuláris betegségek primer prevenciójában. A relatív rizikócsökkenés irányából az abszolút rizikócsökkentés irányába tért át a rizikóstratifikáció szemlélete. Az összes egyénnek az abszolút rizikócsökkentés céljára életmód-változtatás (dohányzás elhagyása, súlycsökkentés, egészséges étrendre áttérés, fizikai aktivitás fokozása) szükséges, illetve magas abszolút CV-rizikó esetén gyógyszeres terápia is.

A kockázatbecslő rendszerek, mint pl. a SCORE-szisztéma segít az adott egyén fennálló kockázati tényezői alapján a megfelelő kockázati csoportba sorolásban, a megfelelő terápiás döntéshozatalban, és az alul- vagy túlkezelés elkerülésében. A SCORE rizikóbecslésén 
alapuló kockázati kategóriákat az újabb európai prevenciós irányelv újra definiálta, eszerint beszélünk igen nagy, nagy, közepes és kis kockázatról, amely egyrészt az elérendő célértékeket, másrészt az alkalmazandó kezelés erélyességét határozza meg. Fiatalabbakban az alacsony abszolút rizikó elfedheti a nagyon magas relatív kockázatot, emiatt a relatív kockázatot felmérő skálák vagy az ún. „rizikó-életkor” meghatározása segíthet abban, hogy kiknek kell közülük intenzív életmód-változtatást javasolni.

A teljes kardiovaszkuláris kockázat azt jelenti, hogy az adott egyénben mekkora valószínűséggel fejlődik ki ateroszklerotikus kardiovaszkuláris esemény egy adott időtartamon belül. A „teljes kockázat” arra a rizikóra utal, amelyet az összes fö rizikófaktor együttes számbavételével kalkulálhatunk ki, köztük a kor, nem, dohányzás, vérnyomás, lipidek.

\section{SCORE-rizikóbecslés}

A SCORE számos ponton különbözik a többi rizikóbecslő rendszertöl. A SCORE a 10 éven belül bekövetkező halálos ateroszklerotikus esemény (infarktus, stroke, aortaaneurizma) kockázatát becsüli meg, míg az egyéb rendszerek a koszorúér-betegség kockázatát. A kardiovaszkuláris mortalitást tudatosan választották, szemben a totális (fatális és nem-fatális) események kockázatával. A nem-halálos események előfordulása nagymértékben függ az alkalmazott definícióktól, illetve a vizsgálóeljárások metodikájától, amelyekkel az esemény igazolható. A fiatal, 40 éven aluliak esetében a SCORE nem igazán alkalmas, mivel az életkortól való erős függés miatt a kockázatot alábecsüli.

Európában, és így Magyarországon is alkalmazott SCORE (Systematic Coronary Risk Evaluation) kevésbé alkalmazható az amerikai populációra, mivel az európai lakosságra, az európai adatok alapján készült. Hasonlóan az amerikai rizikóbecslések - PCE (pooled cohort equations), a Framingham CVD Risk Profile, és a Reynolds risk Score kevésbé alkalmazható az európai és a magyar populációra.

A napi klinikai gyakorlatban a CV-rizikóstratifikáció egész Európában és Magyarországon sem megfelelően müködik. A lakosság életkora emelkedik, nő az elhízottak, és a diabéteszben szenvedők előfordulása, amely a személyre szabott és gyakoribb rizikómeghatározást tesz szükségessé. A gyakorlatban az orvosok végzik a becslést a betegek anamnesztikus adatai, a klinikai jelek, és a laboratóriumi vizsgálatok alapján.

\section{A rizikómeghatározás fó célja}

A rizikómeghatározás fő célja a kezelés támogatása, és döntés a prevenciós kezelés elkezdéséröl, intenzitásáról, és megszakításáról. Általában a magas rizikó- jú egyének rizikótényezőinek kezelése során várható a legnagyobb abszolút rizikócsökkenés. A nagy klinikai vizsgálatok és metaanalízisek alcsoport-elemzései alapján a lipidcsökkentő, a vérnyomáscsökkentő és TAG-gátló kezelések során a relatív rizikócsökkenés nagyjából ugyanaz az összes beteg esetében. Ez azt jelenti, hogy személyre szabott abszolút rizikócsökkentés és individualizált alap kardiovaszkuláris rizikómeghatározás szükséges. A személyre szabott rizikómeghatározás informálja mind a beteget, mind az őt kezelő orvost kardiális állapotáról. A megfelelő rizikóstratifikáció nem helyettesíti az orvost, de segít neki a döntés meghozatalában. A személyre szabott rizikómeghatározás segítségével elkerülhető, hogy az alacsony rizikójú egyéneknél „túl” kezeljük az egyént, illetve magas rizikó esetén „alábecsüljük a kockázatot.

A CV-események jövőbeli megítélésére a különböző populációs csoportokra különböző algoritmusok készültek, amelyek validálva lettek. A legtöbb rizikóbecslő tábla a 10 éves fatális és nem-fatális CV-eseményt jósolja meg olyan egyéneknél, akiknek nem volt az anamnézisükben $\mathrm{CV}$-esemény, és diabetes mellitus sem. A SCORE a 10 éven belül bekövetkező CV-halál előrejelzésére szolgál az európai populációban. A QRISK az iszkémiás szívbetegség, az iszkémiás stroke, vagy TIA előfordulását becsüli meg az Egyesült Királyságban, a PCE (pooled cohort equation) pedig az első ateroszklerotikus esemény előfordulás valószínűséget adja meg a következő 10 évben Észak-Amerikában.

\section{Idő́s egyének rizikóbecslése}

A középkorú egyének esetében a rizikóbecslés megfelelö, de idős emberek esetében túlbecsüli a CV-események előfordulását. Az eredeti SCORE megbízhatóan 65 éves életkor felett nem használható. Ezekre az esetekre speciális rizikó score-t kell használni.

\section{0 évnél fiatalabbak}

Az életkor az egyik legfontosabb prediktor a 10 éves rizikó meghatározásában, így a standard algoritmusok nem alkalmasak a nagyon magas rizikó meghatározására 50 évnél fiatalabb egyének esetében. Az ESC guiedline az 50 évnél fiatalabbak rizikóbecslésére egy kiegészítést javasolt, amely 40 évnél kezdődik. Itt egy relatív rizikó „chart”-ot alkalmaz, amely azt mutatja meg, hogy az azonos életkorú ideális szinthez képest emelkedett-e a rizikója a kijelölt egyénnek.

\section{Magas rizikójú egyének rizikóbecslése}

Azok a betegek, akiknek az anamnézisében szerepel már a diabetes mellitus, vagy további CV-esemény, ma- 
Milyen kockázatbecslési eszközt használhat betegének a CVD megelözésében?

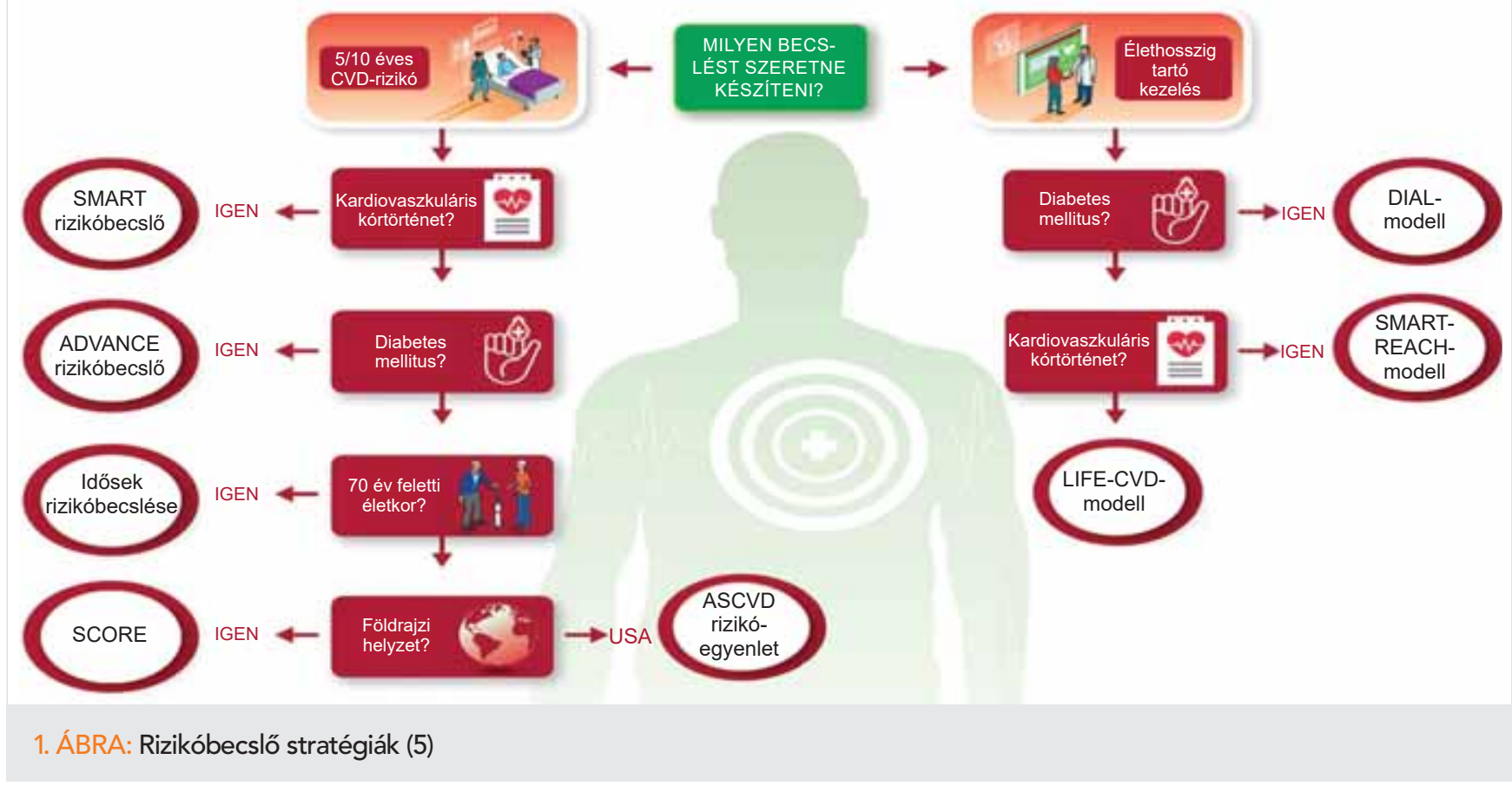

gas, vagy igen magas CV-rizikójúak, pedig individualizálva megfelelő kezelés mellett az alacsonytól, az igen magas CV-rizikó között változhat. Ez alapján érthető, hogy szükség lenne olyan speciális rizikóstratifikációra, amely figyelembe veszi, hogy a beteg cukorbeteg, illetve már klinikailag manifeszt vaszkuláris betegsége van. Ezeket figyelembe véve, az ESC égisze alatt indult el egy projekt egy módosított rizikóstrartifikációs rendszer kidolgozására, amely célja az adott egyénre szabott abszolút $\mathrm{CV}$-rizikó felmérése volt.

Az ESC Kardiovaszkuláris Prevenciós és Rehabilitációs Asszociáció vezetésével elkészített új CV-rizikóbecslés prédikációs algoritmusa a European Journal of Preventive Cardiology 2019 júniusi számában jelent meg. (Risk prediction tools in cardiovascular disease prevention: A report from the ESC Prevention of CVD Programme led by the European Association of Preventive Cardiology - EAPC - in collaboration with the Acute Cardiovascular Care Association [ACCA] and the Association of Cardiovascular Nursing and Allied Professions [ACNAP]. Xavier Rossello, Jannick AN Dorresteijn, Arne Janssen. June 24, 2019 Research https://doi. org/10.1177/2047487319846715)

A javaslat az eddig már megismert, és validált rizikóstratifikációs módszereket együttesen alkalmazza, figyelembe véve a speciális populációkat, és az egyéni különbségeket. Hét javaslatot ad, annak érdekében, hogy a betegek a legjobb rizikóstratifikációs előrejelzésében részesülhessenek.

- Első lépésként el kell dönteni, hogy az egyén anamné- zisében szerepel-e kardiovaszkuláris esemény, vaszkuláris betegség.

- Abban az esetben, ha van igazolt CV-betegség, akkor a továbbiakban a SMART risk score-t kell alkalmazni, amely rákérdez a vaszkuláris betegségek lokalizációjának számára, a beteg hs-CRP értékére, illetve, hogy hány éve diagnosztizálták a vaszkuláris megbetegedést. - Abban az esetben, ha nincs ismert CV-betegség az anamnézisben a következő lépésként tisztázni kell, hogy a betegnek van-e diabetes mellitusa. Ha igen, akkor ez esetben az ADVANCE rizikómeghatározó algoritmus alkalmazandó, amely a $\mathrm{HgIA}_{1 \mathrm{c}}$-értékre, az albuminuriára, pitvarfibrilláció jelenlétére, és a diabétesz fennállásának idejére is rákérdez.

- Ha a beteg 70 éven felül van, akkor az Elderly risk score alkalmazandó. Ha az egyik fenti kategóriába sem esett bele, akkor az egyén földrajzi régiótól függően vagy a SCORE (Európa), vagy az ASCVD risk equation rizikóbecslő táblázat használata javasolt (USA) alkalmazását egészséges egyéneknél, ha nem ismert vaszkuláris betegség.

- Szükség van olyan algoritmusokra is, amelyek az egyénre szabott terápiák eredményeit is tartalmazzák. Ezek is sokat segíthetnek abban, a betegeknek, hogy megértsék miért fontos az életmód-változtatás, és a gyógyszeres kezelés.

- A rizikómeghatározás legyen egyszerü, felhasználóbarát, és adjon azonnal eredményt. Lehetőleg legyen olyan nyelven, amit a beteg megért (1. ábra).

- A projectet U-Prevent.com hónlapon regisztrálták, majd validációs vizsgálatokat végeztek. 


\section{Következtetések}

Az EAPC, az ESC Prevenciós és Rehabilitációs aszszociációja javasolja az U-Prevent online alkalmazását (www.U-Prevent.com) a klinikai gyakorlatban. Ez a weboldal egy interaktív webhely, amely segít kiválasztani a megfelelő kockázat-előrejelző eszközt minden egyes betegnél. Az U-prevent képes felmérni a CV-betegség megjelenésének a rizikóját egészséges embereken, és képes lemérni a kezelés eredményességét. Alkalmazható olyan egyéneknél, akiknél ismert már a CV-betegség, akiknek diabetes mellitusuk van, vagy 70 éven felüliek esetében is.

Az U-Prevent website alkalmazás javasolt a napi klinikai gyakorlatban kardiológusok, diabetológusok, angiológusok mellett a háziorvosok számára is. Elősegíti a rendszer, hogy a betegek is megértsék, hogy miért van szükség a prevenciós tevékenységre, és mit várhatnak az életmód-változtatástól, illetve a gyógyszeres kezeléstől is.

Bár európai centrumokban folyamatban van a validációs folyamat, érdemes lenne hazai viszonylatban is lemérni a rendszer működését nagyszámú vizsgálati alanyon keresztül.
Irodalom

1. Timmis A, Townsend N, Gale C, et al. Atlas Writing Group European Society of Cardiology: Cardiovascular Disease Statistics 2017. Eur Heart J 2018; 39(7): 508-579.

2. Landmesser U, Catapano A. Coronary disease prevention: towards a more personalised approach. European Journal of Preventive Cardiology 2018; 25(17): 1884-1886. https://doi. org/10.1177/2047487318805578

3. Piepoli MF, Hoes AW, Agewall S, et al. 2016 European Guidelines on cardiovascular disease prevention in clinical practice. Eur Heart J 2016; 37: 2315-2381.

4. Cooney MT, Dudina A, D'Agostino R, Graham IM. Cardiovascular risk-estimation systems in primary prevention: do they differ? Do they make a difference? Can we see the future? Circulation 2010; 122: 300-310.

5. Rossello X, Dorresteijn JA, Janssen A, et al. Risk prediction tools in cardiovascular disease prevention: A report from the ESC Prevention of CVD Programme led by the European Association of Preventive Cardiology (EAPC) in collaboration with the Acute Cardiovascular Care Association (ACCA) and the Association of Cardiovascular Nursing and Allied Professions (ACNAP). Eur J Prev Cardiol 2019 Sep; 26(14): 1534-1544. doi: 10.1177/2047487319846715. Epub 2019 Jun 24

6. Müller-Riemenschneider F, Holmberg C, Rieckmann N, et al. Barriers to Routine. Risk-Score Use for Healthy Primary Care Patients: Survey and Qualitative Study. Arch Intern Med 2010; 170(8): 719_ 724. doi:10.1001/archinternmed.2010.66

7. Karmali KN, Lloyd-Jones DM. Implementing Cardiovascular Risk Prediction in Clinical Practice: The Future Is Now. J Am Heart Assoc 2017; 6(4): e006019. Published 2017 Apr 24. doi:10.1161/ JAHA.117.006019 